\title{
Study on the Optimization of Internal Governance Structure in Private Colleges and Universities
}

\author{
Liu Guoyong \\ Xi’an Fanyi University, Xi’an, Shaanxi, China, 710105
}

Keywords: private colleges and universities; relative separation of investment and management; internal governance

\begin{abstract}
This paper combines the theoretical study of research with the case study, based on the stakeholder theory, principal-agent theory, and legal person theory, analyzes the inspiration of the three theories for improving the internal governance in private colleges and universities, analyzes the problems existing in the internal quality of private colleges and universities from three aspects, and explains the reasons behind the lack of university system. Finally, this paper studies the path of optimizing the internal governance structure of private colleges and universities, and proposes to clarify the property rights, establish a property right system suitable for corporate governance of private colleges and universities, improve the board of directors, establish a decision-making system suitable for corporate governance of private colleges and universities, promote the occupational principal system, and establish a corporate governance system suitable for private colleges and universities.
\end{abstract}

\section{Introduction}

Modern economic theory holds that technology, management, intellectual property and intangible assets are all major production factors. Only when all these factors of production achieve optimal combination can they form a competitive production organization. This means that private colleges and universities need to develop in competition, and they also rely on the optimal combination of various factors of production in educational activities. At the same time, it also needs to form a reasonable allocation between sufficient funds, excellent teachers, good management and school culture. The private mechanism is the core influencing factor of the core competitiveness of private colleges.

The mechanism for running private colleges is definitely more flexible than public colleges. For example, in terms of professional construction, it can decide according to the needs of the market and can do its own professional work. However, this does not mean that private universities are better than public universities. These flexible mechanisms of private universities are only the foundation for the formation of its core competitiveness. Compared with public universities, there are inherent deficiencies in financial security, scientific management, teaching quality, and faculty. Only by taking advantage of the advantages of the private sector and learning public experience, can private universities be able to achieve sustainable development. The core of these advantages is the scientific management and operation mechanism, that is, the internal governance structure of private universities. Only by taking advantage of the operating mechanism of private colleges and universities can the superiority of private colleges and universities be brought to the forefront so that they can take the initiative in the fierce market competition.

\section{Theoretical Foundation of Optimizing Internal Governance Structure in Private Colleges and Universities}

\subsection{Stakeholder theory}

Private colleges are a typical stakeholder organization. However, external stakeholders in private 
colleges are less involved in school decision-making. At the same time, internal school administrators and professors tend to consider their own interests too much. Even if they participate in school management, they are only representatives of investors' interests. The most serious is that although the students are also insiders of the school, the students' rights have not been given corresponding attention and attention, resulting in the absence and vacancy of the main body status of students in private universities. From the perspective of the relationship between private colleges and universities, the government attaches great importance to the control of private colleges and universities and despise supervision of private colleges. Compared with public universities, the problems displayed by private colleges are that the phenomenon of investor control is more serious, the student's main position is relatively lacking, and the government has insufficient supervision over the behavior of private colleges and universities. In response to these problems, private colleges should carry out reforms and innovations in the governance structure to safeguard the interests of all stakeholders.

\subsection{Principal-agent theory}

Within the organizational structure of private colleges and universities, the principal-agent relationship is expressed through contractual relationships. The principal is entrusted by the board of directors to manage the school. There are several issues in the principal-agent relationship between the private colleges' board of directors and the principal. The first is the difference between the objectives of the principal and the agent. The principal pursues the maximization of the interest. The agent pursues the highest quality. Although there is an internal connection between the two, the motivation of the agent is different. The second is responsibility. Based on the above analysis, between the board of directors and the principal, it is necessary to establish incentive and restraint mechanisms in the principal-agent relationship. Incentives and constraints are a unified contradictory body, which can not only enable agents to form a driving force for efficiency, but also bring pressure on agents.

\subsection{Legal person theory}

The corporate governance structure of private colleges is the core issue of the governance of private colleges. A sound and perfect corporate governance structure is the key to the realization of corporate governance. In the development process of private colleges, it is necessary not only to consider the interests of investors, but also to take into account other interests such as teachers and students. For now, the board of directors system is the best choice for the corporate governance structure of private colleges. Under this system, the board of directors is the highest decision-making body in the school, making decisions on the school's development goals and major initiatives, and safeguarding the interests of the school. The board of directors is responsible for the selection and appointment of the principal and the principal is responsible to the board of directors. In this way, the interests of investors can be guaranteed, the quality of schools can be guaranteed and private colleges can finally get rid of the family-style management to embark on the road of sustainable development.

\section{Problems and Causes of the Internal Governance Structure in Private Colleges and Universities}

\subsection{The unlimited rights, checks and balances of the board of directors}

Table 1. Problems of board of directors in private colleges

\begin{tabular}{cr}
\hline No. & Problems \\
\hline 1 & The composition of the board of directors is highly arbitrary and no corresponding access \\
mechanism has been established
\end{tabular}

The board of directors is the highest decision-making body in private universities. If there is no 
check and balance mechanism, this decision-making body will become a free decision-making body. Even if a board of directors is established, it will be the same as a family-owned management model. Judging from the current situation, the board of directors of private colleges has the following problems as showed in Table 1.

\subsection{Manager's identity crisis and its incentive problems}

Investors in private colleges are very clear that investment should be separated from management, and investors should not directly manage schools. This is an inevitable requirement for the development of private colleges at a certain stage, and is also the law of education. In order to be separated, the principal should be hired, and there must be a management level. In order to give full play to the enthusiasm of the management level, there must be an incentive mechanism. Many private colleges have formed their own mechanism and have done some positive exploration on the management incentives, but there are still a lot of problems, which are highlighted in two aspects, such as no legal protection for the principal's rights and interests, and management's personal interests are not related to the profits of private universities.

\subsection{Main causes of the internal governance of private colleges and universities}

First is the lack of modern university system. Modern universities should do their jobs in accordance with the law, autonomous management, democratic supervision, and social participation. This is also a question that private universities must consider when improving their internal governance structure. In other words, a sound internal governance structure is based on the premise and foundation of a modern university system. The current problems in the internal governance of private colleges and universities are due to the lack of these basic systems.

Second is the separation of management rights and teaching rights, private colleges need management, but they also need to operate, or use the concept of management to carry out school construction, especially in the aspects of talent introduction, professional setup, and personnel training modes, and they need stronger market awareness. However, the general status of private colleges and universities is that the board of directors is holding the right to operate the school. For example, if people's control rights and financial management checks are held in the hands of the chairman, the principal's power cannot reach the position, and these powers are not guaranteed. Teaching in the sense of cultivating talents that do not need the market

\section{Optimization of Internal Governance Structure in Private Colleges and Universities}

\subsection{Define property rights and establish an incentive property rights system}

As an economic organization specialized in the division of labor, the university can be divided into several basic powers such as ownership, control, business control, income, and disposal rights, based on the characteristics of the education industry. According to the economic theory of property rights, in the category of property rights, ownership is the basis of other powers. Obviously, the existence of ownership is in the existence of income right. Therefore, the right to income is the key to the issue of property rights in private colleges, and also the theoretical basis for investors to obtain a "reasonable return." The ownership should be dynamic in private colleges and universities. In the early stage of school establishment, investors had college ownership and faculty members only obtained contracted income. However, after the college has been running for a period of time, the ownership arrangement must be adjusted. Investors and managers should share ownership.

\subsection{Improve the board system and establish a scientific decision-making mechanism}

In the development process of private colleges, the chairman of the board often exercises power in the capacity of investor and investor, thus making the board of directors an advisory or advisory organization. The board of directors does not establish scientifically sound rules and regulations. The College Board is often monopolized by the family. Personnel and financial affairs are not open, and the short-term behavior of education investment is serious. The current private College Board system 
can be improved from the following aspects, as showed in Table 2.

Table 2. Actions need to be done for private College Board

\begin{tabular}{cc}
\hline No. & Actions \\
\hline 1 & Establishing the Admission System for Directors of Private Colleges. \\
2 & Establish and improve the regulations of the board of directors. \\
3 & $\begin{array}{c}\text { Improve the organizational structure of the board of directors and clarify the } \\
\text { relationship between the principal and the board of directors. }\end{array}$ \\
\hline
\end{tabular}

\subsection{Establish a concept of stakeholders' common governance}

At present, the checks and balances mechanism of private colleges is relatively deficient, and private colleges should set up a supervisory board. There is a significant difference between the board of supervisors and the board of supervisors in guaranteeing the rights and interests of investors, the aim of which is to protect the rights and interests of the educated and not be infringed on to a greater extent. From the actual situation of the colleges, the members of the board of supervisors should consider three aspects, one is the representative of the educational administration, such as the current Supervisory Commissioner, second is the representative of the Faculty of the school, third is the student or the parent and the donor.

\section{Conclusion}

Private colleges establish an internal governance model with relatively separate investment and management, which will help realize the effective management and sustainable development of private colleges. The theoretical basis for constructing this model is stakeholder theory, principal-agent theory, and corporate governance theory. The precondition for the construction of this model is to establish a property right system that is in line with the corporate governance of private colleges. In the framework of a relatively separate investment and management, the core content of the internal governance model of private colleges is to take the three sides of decision-making, implementation and supervision, namely, the board of directors, the school affairs council, and the board of supervisors perform their duties.

\section{Acknowledgement}

The key Research Project of Education and Teaching Reform in Shaanxi Province: research on the Optimization of Internal Governance structure based on the improvement of Educational and Teaching quality in Private Colleges and Universities, item No.: 17BG028.The key Project of Teaching Reform Research of Xi'an Translation College: the Research on the Optimization of the Internal Governance structure of Private Universities in Shaanxi Province from the Perspective of "people's Promotion Law", item No.: J17A05

\section{References}

[1] Brian R. Challas, Corporate Law: Theory, Structure, and Operation, Beijing Law Press, 2001.

[2] Zhang Jianbo, Research on Sustainable Development of Private Colleges [M]. Changsha, University of Defense Technology Press, 2007

[3] Hu Wei, Development and Regulation of Private Education [M]. Beijing, Education Science Press, 2000

[4] Yu Haishao, Governance: A New Concept of University Management [J]. Heilongjiang Higher Education Research, 2003(1) 